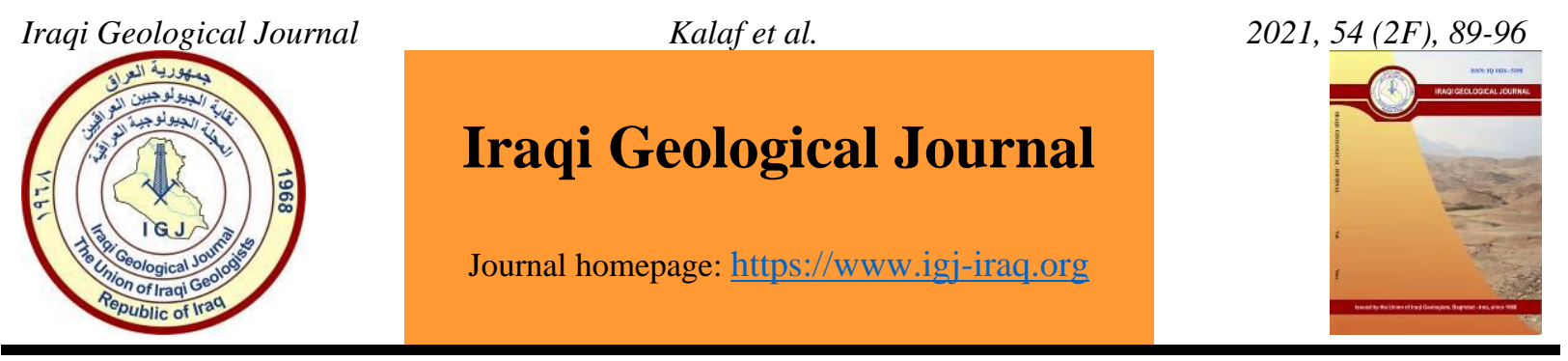

\title{
Geo-Engineering Study of Selected Soils for Cement Industry in Al-Kifil District, Babylon, Central Iraq
}

\author{
Muhsen O. Kalaf ${ }^{1}$, Mohammed L. Hussien ${ }^{2}$ and Bilal M.A. Issa ${ }^{3, *}$ \\ 1 Department of Applied Geology, College of Science, University of Babylon, Iraq \\ 2 Department of Building and Construction Engineering Technologies, Al-Mustaqbal University College, Iraq \\ 3 Department of Applied Geology, College of Science, University of Babylon, Iraq \\ * Correspondence: bilal.is.1985@gmail.com
}

Received: 22 September 2021; Accepted:19 October 2021; Published: 31 December 2021

\begin{abstract}
The research was conducted on nine pits for selected soils in Babylon, in the Al-Kifl region in particular. It aims to find the relationship between the physical and chemical properties of the studied soil and its suitability in the cement industry. Nine samples of different depths were taken with a simple description of the soil in the fieldwork stage. As for the stage of laboratory tests, it included testing the grain size distribution to find the percentage of sand, silt, and clay, and Atterberg limits to find plasticity. It was found through these tests that the soil is silty clay and has low plasticity except for samples no. 5, and 6, which were clayey soil with low plasticity. The relationship between physical properties depends on the property of the grain size distribution, as it is the function of the rest of the properties. Chemical tests of the samples and comparing the ratios of their oxides with the standard specifications of the Kufa plant laboratory turned out to be suitable for the manufacture of ordinary Portland cement, as the study area is considered a good quarry for the clays used in such industries.
\end{abstract}

Keywords: Soils; Cement; Physical properties; Chemical properties; Grain size distribution; Atterberg limits

\section{Introduction}

Soils are used as raw materials in construction industries such as bricks, cement, and ceramics, but each has specific characteristics (Al-Owaidi, 2013; Awadh and Al-Owaidi 2020). Cement is an important structural material that is used in construction, as well as an important component of concrete. Cement is made from limestone and clays after mixing them in certain proportions (Ali et al., 2014). In soils prepared for the cement industry, specification is required of silicon and aluminum oxides, and other important secondary oxides. These oxides can be identified through chemical examinations. These oxides, which are present in clays and limestone will react to form clinker compounds (Abdulla and Majeed, 2021, Awadh and Al-Owaidi, 2021). The raw materials are burned after good mixing at high temperatures in kilns for the cement industry (Haldar, 2018, Awadh, S.M. and Al-Owaidi, 2021), where cement compounds are formed, and then gypsum is added to them in the final stages. Continuous testing operations may take place before and during mixing to ensure the values of oxides entering the industry from raw materials to obtain a product that meets the standard specifications of cement. The investigation stage of the clays for a specific quarry is depending on the values of silica, alumina, iron oxides, calcium carbonate, and magnesium, as well as sulfates, which are determined by the so-called laboratory specification, to match the existing oxides in the limestone, which enter a main potential DOI: 10.46717 /igj.54.2F.8ms-2021-12-25 
within the raw materials (Reyes et al., 2017). Awad and Awadh (2020) and Awadh, and Awad (2021) have determined the evaluation of the clay from the ancient layers for the manufacture of the cement and bricks (ordinary and perforated) as an additional source for Cement industry. Shaker, (2019) studied the physical, chemical, and mineralogical properties in this area and investigated the air pollution of the contaminated gas and dust of the Private brick factories. Also, a study of the effect of different rice husk ash on the geotechnical properties of clay soils, (Duong and $\mathrm{Nu}, 2020$ ) improving their quality, mixing them with cement to enhance their strength, and comparing them with soils not mixed with rice husks. The research aims to study the relationship between some physical and chemical properties of the soil samples and their suitability for use as a raw material for the cement industry.

\section{Geology and Topography of the Study Area}

In general, the geology of the study area is not different from the geology of the sedimentary plain because it is located within it, where the sediments that cover the study area return to the era in which the rivers formed, which is the Quaternary era. Exposure to a series of periodic precipitation and weather conditions as a result of climate changes during the Ice Age is what distinguishes this sedimentary plain (Jassim, 2006). The largest part of the research area from the geological point of view is covered by flood plain deposits and fluvial sediments. The northeast, eastern and southeastern part of the study area is generally, covered with aeolian deposits (Al-Jeafir, 2020). The surface of the study area, in general, is characterized by its flatness and its general slope from north to south, that the equal elevation line $(65 \mathrm{~m})$ above sea level passes in its northern parts in Babylon Governorate, while the equal elevation line (25 m) above Sea level passes through its southern parts in the Babylon.

\section{Materials and Methods}

The research included the stage of fieldwork, laboratory work, and office work.

\subsection{The Fieldwork}

The location of the field area is in the middle of Iraq, which is within the sedimentary plain, and this area is the Babylon Governorates, where they lie between longitude east

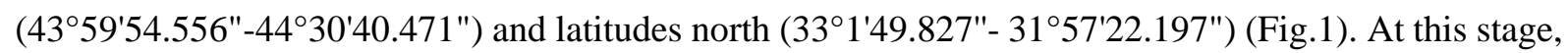
an exploratory tour of the study area was carried out and verified that it is suitable from a human and economic point of view and that it is devoid of the manifestations of agriculture, buildings, and public facilities and far from the nearest cement industry, which is the Al-Kufa Cement Plant. After the survey, three pits were dug shown on the map of the study site, and samples were brought to conduct the laboratory tests required in the research. The studied area is devoid, and its soil, in general, is silty clay, with the rate of sand, where nine holes were selected, the coordinates of the studied drilling sites were recorded using the GPS device and the size of the study area it was $\left(931484.5 \mathrm{~m}^{2}\right.$ ) (Table 1).

\subsection{Laboratory Work}

The laboratory tests were performed for the samples that were brought from the study area, and they included:

- Physical Tests, which are: moisture content, particle size distribution, and atterberg limits. The laboratory test was carried out on the nine samples extracted from the holes by giving a dry particle size analysis, using standard test methods for particle-size distribution of soil utilizing sieve analysis (ASTM D 6913 / D 6913M - 17) to separate sand from silt and clay. The wet test method also was achieved by using the standard test method for particle-size distribution of fine-grained 
soils using the sedimentation (hydrometer 151H) analysis (ASTM D7928 - 17) to separate the silt from the clay for each sample.

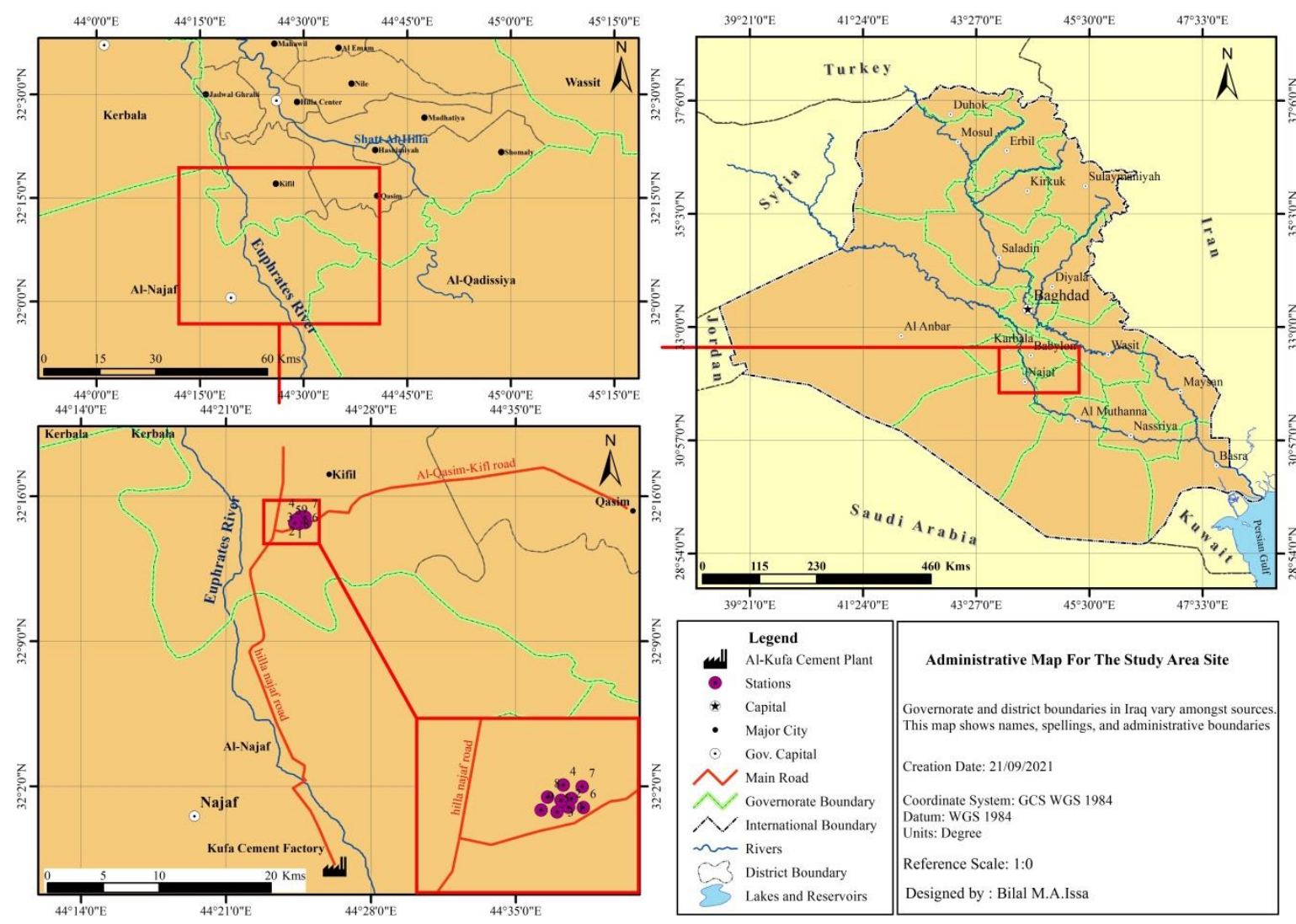

Fig. 1. Map of the study area showing stations sites

Table 1. Stations of the study area and their coordinates system.

\begin{tabular}{ccc}
\hline Station No. & \multicolumn{2}{c}{ Coordinate System } \\
\hline & Longitudes & Latitudes \\
1 & $44^{\circ} 23^{\prime} 2.079^{\prime \prime}$ & $32^{\circ} 10^{\prime} 32.5302^{\prime \prime}$ \\
2 & $44^{\circ} 22^{\prime} 57.9396^{\prime \prime}$ & $32^{\circ} 10^{\prime} 26.979^{\prime \prime}$ \\
3 & $44^{\circ} 22^{\prime} 54.4686^{\prime \prime}$ & $32^{\circ} 10^{\prime} 32.4294^{\prime \prime}$ \\
4 & $44^{\circ} 24^{\prime} 35.481^{\prime \prime}$ & $32^{\circ} 15^{\prime} 0.0822^{\prime \prime}$ \\
5 & $44^{\circ} 24^{\prime} 30.978^{\prime \prime}$ & $32^{\circ} 14^{\prime} 40.6206^{\prime \prime}$ \\
6 & $44^{\circ} 24^{\prime} 50.0328^{\prime \prime}$ & $32^{\circ} 14^{\prime} 43.8642^{\prime \prime}$ \\
7 & $44^{\circ} 24^{\prime} 49.2228^{\prime \prime}$ & $32^{\circ} 14^{\prime} 58.8654^{\prime \prime}$ \\
8 & $44^{\circ} 24^{\prime} 24.0834^{\prime \prime}$ & $32^{\circ} 14^{\prime} 51.3672^{\prime \prime}$ \\
9 & $44^{\circ} 24^{\prime} 19.4214^{\prime \prime}$ & $32^{\circ} 14^{\prime} 42.039^{\prime \prime}$ \\
Size of study area & $931484.5 \mathrm{~m}^{2}$ \\
\hline
\end{tabular}

The last part of the laboratory tests is represented by using standard test methods for liquid limit (L.L.\%), plastic limit (P.L.\%), and plasticity index (P.I.\%) of soils " Atterberg Limits" (ASTM D 4318 17e1). Atterberg limits are affected by the amount and nature of the clay minerals content in the soil, where plasticity is an important factor in determining the operability of clays or clay mixtures and their application to construction industries such as bricks, ceramics, and pottery (Al-Waeli, 2018), and it is also a good indicator of the phases of the main clay minerals in the soil (Yongue et al., 2016 and Duggal, 2008). 
- Chemical Tests: included examinations for silica oxides $\left(\mathrm{SiO}_{2}\right)$, Aluminum oxide $\left(\mathrm{Al}_{2} \mathrm{O}_{3}\right)$, iron oxide $\left(\mathrm{Fe}_{2} \mathrm{O}_{3}\right)$, calcium $\left(\mathrm{CaCO}_{3}\right)$, and magnesium $\left(\mathrm{Ca}, \mathrm{Mg}\left(\mathrm{CO}_{3}\right)\right.$ carbonate, as well as sulfates $\left(\mathrm{SO}_{3}\right)$.

\section{Results and Discussion}

Through the fieldwork, and as shown on the map of the study area (Fig.1), the study area is somewhat free from housing and agriculture, and after the groundwater level. It is environmentally, valid as an earthen quarry at a depth of approximately $3 \mathrm{~m}$, for cement production, and the distance to the Kufa cement plant is suitable at about $35 \mathrm{~km}$. It can be used as a new quarry to be added to the quarries of that factory. Through the laboratory tests, that were conducted on the samples taken from the sites, where the manual excavation process was taking place to identify the geotechnical properties. The soil was mixed for each site and a sample representing the site was obtained by the well-known modeling method. The physical and chemical examinations are shown in Tables 2 and 3and Figs. 2,3, and 4 .

Table 2. The results of physical examinations of soil samples studied.

\begin{tabular}{cccccccc}
\hline Station & \multicolumn{3}{c}{ Grain Size Distribution } & \multicolumn{3}{c}{ Atterberg Limits } & \multirow{2}{*}{ USCS } \\
\cline { 2 - 6 } No. & Clay\% & Silt\% & Sand $\%$ & L.L.\% & P.L.\% & P.I.\% & \\
1 & 65 & 23 & 12 & 42 & 30 & 12 & ML \\
2 & 53 & 22 & 25 & 36 & 27 & 9 & ML \\
3 & 57 & 30 & 13 & 38 & 28 & 11 & ML \\
4 & 61 & 24 & 15 & 40 & 27 & 13 & ML \\
5 & 50 & 31 & 19 & 33 & 21 & 12 & CL \\
6 & 57 & 29 & 14 & 34 & 22 & 12 & CL \\
7 & 53 & 26 & 21 & 38 & 28 & 10 & ML \\
8 & 60 & 22 & 18 & 41 & 30 & 11 & ML \\
9 & 61 & 20 & 19 & 41 & 30 & 11 & ML \\
\hline
\end{tabular}

Table 3. The results of chemical tests for the studied soil samples.

\begin{tabular}{ccccccc}
\hline Station No. & $\mathbf{S i O}_{2}$ & $\mathbf{F e}_{2} \mathbf{O}_{\mathbf{3}}$ & $\mathbf{A l}_{\mathbf{2}} \mathbf{O}_{\mathbf{3}}$ & $\mathbf{M g O}$ & $\mathbf{C a C O}_{\mathbf{3}}$ & $\mathbf{S O}_{\mathbf{3}}$ \\
\hline 1 & 55.13 & 4.04 & 13.44 & 6.68 & 20 & 0.42 \\
2 & 57.94 & 4.12 & 12.92 & 6.30 & 19.2 & 0.29 \\
3 & 56.02 & 4.07 & 12.98 & 6.35 & 20.5 & 0.33 \\
4 & 54.03 & 3.89 & 14.02 & 5.87 & 22.1 & 0.33 \\
5 & 54.11 & 4.11 & 13.55 & 6.03 & 19.3 & 0.44 \\
6 & 55.04 & 4.25 & 13.60 & 6.55 & 21.5 & 0.39 \\
7 & 57.90 & 3.99 & 12.90 & 6.31 & 18.9 & 0.46 \\
8 & 56.1 & 3.79 & 13.11 & 5.96 & 21.3 & 0.37 \\
9 & 56.44 & 4.09 & 13.08 & 6.44 & 21.7 & 0.32 \\
\hline
\end{tabular}




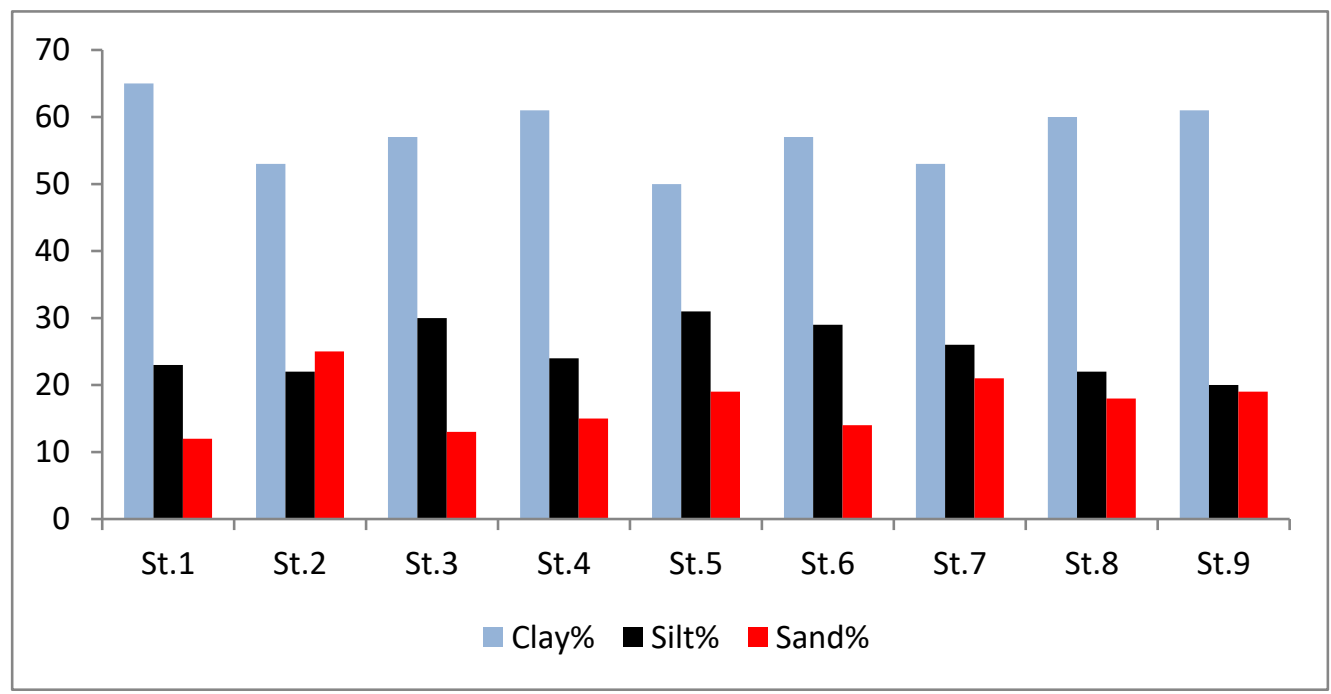

Fig. 2. Distribution of grain size analysis in the study area

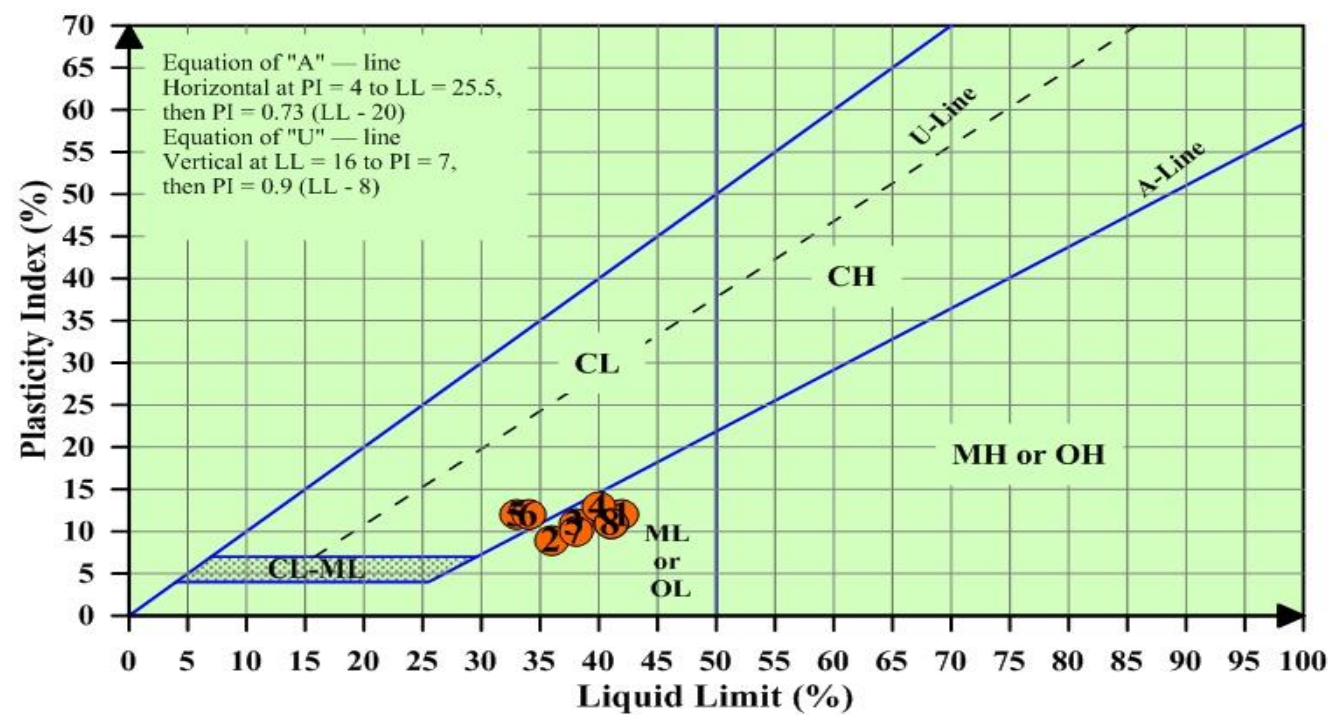

Fig. 3. Atterberg Limits examination in the study area by using plastisity chart

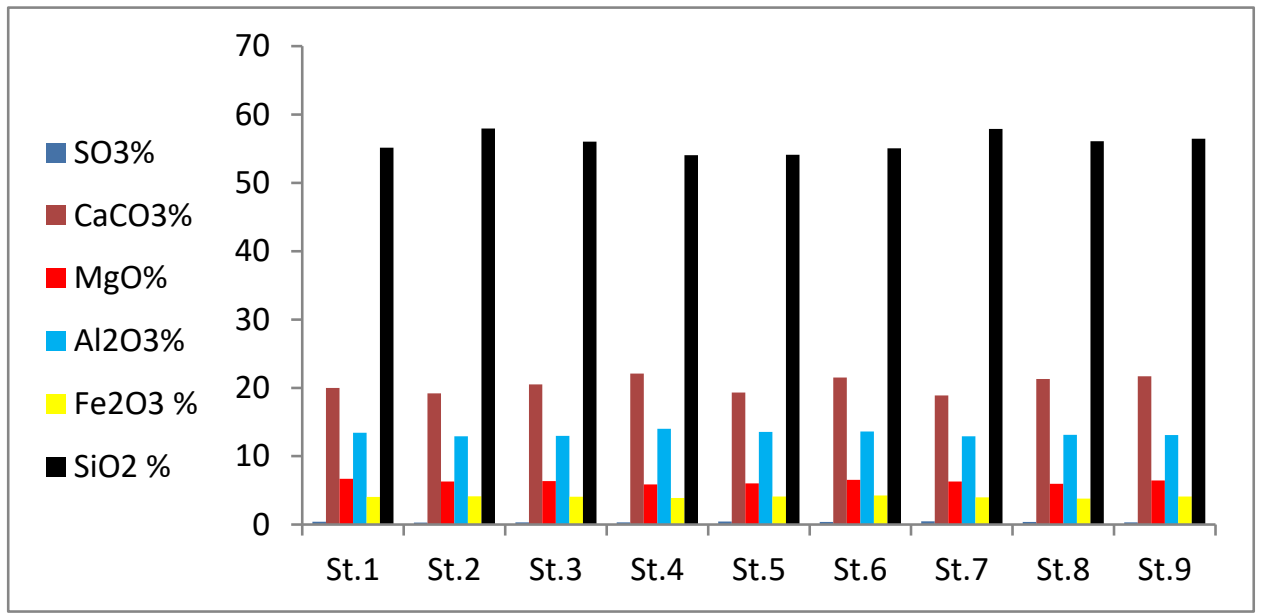

Fig. 4. Chemical tests in the investigated sites 
By examining the grain size analysis of the soil of the study area, it was found that it is silty clay with a small percentage of sand. The percentage of clay ranges between 53-65\% with an average of $57.44 \%$. The percentage of silt between $20-31 \%$ with a mean of $25.22 \%$, and the percentage of sand between $12-25 \%$ with a mean of $17.33 \%$. It is of low plasticity according to the Standard Soil Classification, (CL) for st. 5 and6 and the rest of the samples are ML. It is like the rest of the soil of the sedimentary plain, where this characteristic is of the grain size distribution of the near depths with this description. However, the geological circumstances are similar to those of sedimentation, and it is technically suitable for the cement industry (Table 2). As the results of the chemical tests (Table 3), which is the most important, it is clear that the participation of clay oxides with limestone constitutes the total oxides of the produced cement.

Table 4. Laboratory specifications for the raw materials used in the cement Kufa plant.

\begin{tabular}{|c|c|c|c|c|c|}
\hline \multicolumn{2}{|l|}{ Limestone } & \multicolumn{2}{|l|}{ Clay } & \multicolumn{2}{|l|}{ Gypsum } \\
\hline Component & Limits & Component & Limits & Component & Limits \\
\hline $\begin{array}{l}\text { Calcium and magnesium } \\
\text { carbonate ratio }\end{array}$ & $<85 \%$ & Silica & $38-42 \%$ & $\begin{array}{l}\text { Sulfate ratio for } \\
\text { secondary gypsum }\end{array}$ & $\geq 36 \%$ \\
\hline Magnesium carbonate ratio & $\leq 5 \%$ & $\begin{array}{l}\text { Coefficient of } \\
\text { Silica }\end{array}$ & 2.3 . & $\begin{array}{l}\text { Sulfate ratio for primary } \\
\text { gypsum }\end{array}$ & $\geq 40 \%$ \\
\hline Sulfate ratio & $\leq 1 \%$ & $\begin{array}{l}\text { Coefficient of } \\
\text { Alumina }\end{array}$ & $1.6-1.8$ & $\begin{array}{l}\text { Insoluble substances for } \\
\text { secondary gypsum }\end{array}$ & $\leq 10 \%$ \\
\hline The largest piece of stone & $\begin{array}{l}\leq \\
25 \mathrm{~mm}\end{array}$ & Sulfate ratio & $\leq 1.5 \%$ & $\begin{array}{l}\text { Insoluble substances for } \\
\text { primary gypsum }\end{array}$ & $\leq 5 \%$ \\
\hline Moisture content & $\leq 12 \%$ & - & - & - & - \\
\hline Alkali ratio & $\leq 0.1 \%$ & - & - & - & - \\
\hline Sand & & \multicolumn{2}{|c|}{ Iron Ore } & \multicolumn{2}{|l|}{ Oil } \\
\hline Component & Limits & Component & Limits & Component & Limits \\
\hline Silica & $\geq 80 \%$ & Sulfate ratio & $\leq 1 \%$ & Spill point & $\leq 21 \mathrm{C}$ \\
\hline Sulfate ratio & $\leq 1.5 \%$ & Iron dioxide ratio & $\geq 50 \%$ & Sulfate ratio & $\leq 3.5 \%$ \\
\hline- & - & $\begin{array}{l}\text { Aluminum } \\
\text { dioxide ratio }\end{array}$ & $\leq 10 \%$ & Residual carbon ratio & $\leq 6.5 \%$ \\
\hline- & - & $\begin{array}{l}\text { Silicon dioxide } \\
\text { ratio }\end{array}$ & $\leq 20 \%$ & $\begin{array}{l}\text { Impurities ratio, } \\
\text { including water }\end{array}$ & $\leq 1 \%$ \\
\hline- & - & $\begin{array}{c}\text { The largest piece } \\
\text { of iron ore }\end{array}$ & $\leq 25 \mathrm{~mm}$ & $\begin{array}{c}\text { Density at temperature } \\
15.60 \mathrm{C}\end{array}$ & $\begin{array}{c}\leq \\
0.95 \%\end{array}$ \\
\hline
\end{tabular}

Referring to the laboratory specification of Kufa Cement Factory, which is a Special lab specification (Table 4) because there is no standard specification for raw materials in Kufa Cement Factory, and comparing it with the results of the laboratory examinations, it was found that it is somewhat suitable, but it needs to know the tests of the complementary limestone for the raw materials, where the percentage of silica $\left(\mathrm{SiO}_{2}\right)$ ranges between 54.03 - 57.94 which may be more than the limits of the specification of Kufa Cement Factory (silica $\geq 38 \%$ ). That high proportion of silica is attributed to the nature of the dominated sediments in the study area, which are; fluvial sediments, flood plain deposits, wind sand deposits, and local marsh sediments (Al-Bassam, 2000). The percentage of iron oxide $\left(\mathrm{Fe}_{2} \mathrm{O}_{3}\right)$ is between $3.79-4.12$ which is fairly acceptable. The percentage of alumina $\left(\mathrm{AL}_{2} \mathrm{O}_{3}\right)$ ranges between 12.9 - 14.02 which is suitable for production. The percentage of magnesium oxide $(\mathrm{MgO})$ fluctuates between 5.87 and 6.98, which is less than the Kufa Cement specification $(\leq 8.0)$ and considered suitable to the cement quality. However, its increase causes problems in the quality of produced cement, especially when it is used in concrete due to the formation of magnesium hydroxide when moisture is present. The percentage of calcium carbonate $\left(\mathrm{CaCO}_{3}\right)$ ranges between 18.9 to 22.1, which in turn, participates with limestone to obtain calcium oxide. The percentage of sulfate $\left(\mathrm{SO}_{3}\right)$ 
ranges from 0.29 to 0.44 , and it is suitable according to the limits of the specification $(\leq 1.5 \%)$, whereas its increase causes problems when using cement produced in concrete (Reyes et al., 2017).

\section{Conclusions}

- The physical and chemical evaluation of the main raw materials used in the production of Portland cement, which are clays and limestone, before starting production is an initial but important step. It requires continuous evaluation and monitoring when used in industry, because these properties, particularly chemical characteristics, are dependent on the product's quality.

- From the environmental point of view, the study area is suitable for cement production purposes.

- The process of evaluating clays alone without knowing the properties of limestone is not sufficient, especially calcium carbonate and magnesium oxide.

\section{Acknowledgements}

The authors are very grateful to the Editor in Chief Prof. Dr. Salih M. Awadh, the Secretary of Journal Mr. Samir R. Hijab. and the Technical Editors for their great efforts and valuable comments.

\section{References}

Abdulla, R., Majeed, N.,2021. Enhancing engineering properties of expansive soil using marble waste powder. Iraqi Geological Journal, 54 (1E), 43-53.

Al-Auweidy, M. R., 2013. Qualitative, quantitative, and radiological assessment of marl layer in the Euphrates Formation for Portland cement industry in Kufa cement quarry at Al-Najaf Governorate. Published M.Sc. Thesis, College of Science, University of Baghdad.

Al-Bassam, K.S. 2000. Geological impacts on the Euphrates River environments. The national program for the optimal use of water resources in the Euphrates River basin.

Ali, K. K., Awadh, S. M., and Al-Auweidy, M. R., 2014. Assessment natural radioactivity of marl as raw material at Kufa Cement Quarry in Najaf Governorate. Iraqi Journal of Science, 55(2A):454-462.

Al-Jeafir, M.L., Hussian, A., 2020. Sedimentological, mineralogical, and environmental study of the Euphrates river from Babylon to Basrah, Iraq. Unpublished Ph.D. Thesis, University of Basrah, Iraq. 238 pp.

Al-Waeli, M.M., 2018. Basics of soil mechanics and its engineering applications. Baghdad and Jordan. Tigris Library, Al-Wadeh Publishing.

ASTM D 4318., 2017. Standard test methods for liquid limit, plastic limit, and plasticity index of soils. Annual Book of ASTM Standards. American Society for Testing and Materials.

ASTM D6913, D6913M., 2017. Standard test methods for particle-size distribution (gradation) of soils using sieve analysis.

ASTM D7928., 2017. standard test method for particle-size distribution (gradation) of fine-grained soils using the sedimentation (hydrometer) analysis. Annual Book of ASTM Standards. American Society for Testing and Materials.

Awad, A. M., Awadh, S. M.,2020. Reserve estimation of Late Miocene Injana claystone beds for portland cement and brick industry, Middle of Iraq. Iraqi Geological Journal, 53, (1D), 16.

Awadh, S.M. and Al-Owaidi, M.R., 2020. Application of triangles method for quantitative estimation of marl reserve in Euphrates formation, middle of Iraq. The Iraqi Geological Journal,.53 (2A), 35-49.

Awadh, S.M. and Al-Owaidi, M.R., 2021. Designing Raw Mix for Manufacturing Portland Cement using Euphrates Formation Marl Instead of Clays. The Iraqi Geological Journal, 54 (2D), 87-97.

Awadh, S.M. and Awad, A.M., 2021. Evaluation of the Injana claystone from Central Iraq for the brick industry. Kuwait Journal of Science, 48(2).

Duong, N. T., Nu, N. T.,2020. Effect of different types of rice husk ash on some geotechnical properties of cement-admixed soil. Iraqi Geological Journal, 53(2C),1-12.

Haldar, S. K., 2018. Mineral Exploration (Second Edition) Principles and Applications, Handbook, Published by Elsevier.

Jassim, S.Z., Goff, J.C., 2006. Geology of Iraq. First ed., Czech Republic, 314 pp. 
Reyes, R. S. A., Alujas, A. D., Betancourt, S. R., Alberto, C. L. R., Fernando, J. M. H., Rodríguez, S. B., Rodríguez, C. A. L., Hernández, J. F. M. 201.7 Assessment of Cuban Kaolinitic Clays as Source of Supplementary Cementitious Materials to Production of Cement Based on Clinker-Calcined ClayLimestone Proc. 2nd Int. Conf. on Calcined Clays for Sustainable Concrete Springer pp 21-28.

Shaker, E. H., 2019. Environmental Assessment and Impact of Brick Industry on Human Health at Abu Smeache Area, Southwest Babylon Government, Iraq, Unpublished M.Sc Thesis, College of Science, University of Babylon, 22-25.

Yongue, F. R., Ndimukong, F., Njoya, A., Kunyukubundo, F., Mbih, P.K., 2016. Mineralogical, geochemical, physical characteristics and properties of their fired products. Journal Asian Ceramic Society, 2016. 